\title{
How experienced professionals develop their expertise in work-based higher education: A literature review
}

\author{
Anna Wallin
}

Researcher

Faculty of Education, University of Tampere

Åkerlundinkatu 5, 33014 University of Tampere, Finland

+358503187578

anna.wallin@uta.fi

Petri Nokelainen*

Professor

Laboratory of Industrial and Information Management, Tampere University of Technology

Korkeakoulunkatu 10, 33720 Tampere University of Technology, Finland

+358405574994

petri.nokelainen@tut.fi

Susanna Mikkonen

Researcher

Faculty of Education, University of Tampere

Åkerlundinkatu 5, 33014 University of Tampere, Finland

+358505099039

susanna.mikkonen@uta.fi

* Corresponding author 


\title{
How experienced professionals develop their expertise in work-based higher education: A literature review
}

\begin{abstract}
This study explores how industry-university partnerships contribute to the expertise development of highly experienced professionals, and what kind of challenges such development entails. We used an integrative approach to review literature and acquire a deeper understanding of how previous research has described the development of expertise in work-based postgraduate higher education. Consistent with earlier research, this review confirms that expertise is developed through transforming and integrating theoretical, practical and self-regulative knowledge. Results suggest that (1) learners should be supported but also allowed to self-manage their learning in order to build agency and self-regulative skills, (2) continuous problem solving with ill-defined, non-routine problems should be encouraged along with challenges that trigger learning, (3) learners' personal transformation process and change of identity should be supported, and (4) expertise development should be viewed as an ongoing, contextdependent and individualised process.
\end{abstract}

Keywords: expertise development, higher education, work-based, professional doctorate, postgraduate education, professional development

\section{Introduction}

The interplay between the student as a learner, the university and the working environment is an important aspect in increasing the relevance of higher education (Wall 2017). Although work-based learning approaches are widespread in higher education, an understanding of what makes them effective and how they should be designed is limited (Feldmann 2016). One of the challenges is the lack of concrete integration of academic and work-based knowledge through guidance practices (Endedijk and Bronkhorst 2014). According to a recent study, successful integration of academic and workplace guidance requires matching expert profiles of the learner and the advisors (Hytönen et al. 2016). 
In addition to university and workplace partnerships, the type of upskilling needed by the workforce has been constantly changing over the decades (Brynjolfsson and McAfee 2014). Rapid technology development, digitalisation of work processes and changes in the organisation emphasise the value of learning throughout one's working career (Collin, Van der Heijden, and Lewis 2012; Tynjälä 2013). Employers need practitioners who can solve complex problems and can acquire and develop new knowledge (Baartman, Gulikers, and Dijkstra 2013). To maintain a strong position in the education market, research suggests that universities should increase their participation in the development of the existing workforce by imparting higher-level skills through, for example, part-time in-service courses (Lester and Costley 2010), postgraduate education (Mylopoulos, Regehr, and Ginsburg 2011) and further education (Lucas and Unwin 2009).

Earlier reviews of industry-university partnerships have been thematic or conceptual and have concentrated on the integration of work-based learning and formal education (Garnett 2016; Lucas 2007; Tynjälä 2008; Tynjälä, Välimaa, and Sarja 2003). Thus, no systematic review has been conducted on these topics. A salient feature of this systematic review is that it explores the development of expertise across the boundaries of higher education and industry. More specifically, it explores how industry-university partnerships contribute to the expertise development of highly experienced professionals. The challenges in this format of expertise development are also examined. We seek to provide a deeper understanding into how previous research has described the development of expertise in work-based postgraduate higher education. In this study, we define work-based postgraduate higher education quite broadly, encompassing all forms of higher education that support the continuing professional development of qualified and experienced professionals (e.g. further education, professional training programmes, continuing education).

The following research questions guide the current study: 
Research Question 1: How does experienced professionals develop their expertise during work-based higher education (WBHE)?

Research Question 2: What kind of challenges does WBHE entail for expertise development and how can WBHE support professionals' expertise development?

First, we examine existing research on expertise development and expert learning.

Next, we describe our literature review process and findings. Finally, we discuss the practical implications of the findings and the needs for future research in the field of expertise development and work-based higher education (WBHE).

\section{Expertise development research}

Several theoretical frameworks describe how experts learn, what characterises expert performance and how novices or non-experts become experts (e.g., Ericsson 2006). Much of the work on expertise proposes developmental stage models, in which expertise develops in a stable and linear fashion, with characteristics and development activities defined at each stage (e.g., Chi, Glaser, and Rees 1981; Dreyfus and Dreyfus 1986; Fleck 1998; Herling 2000). These relative approaches indicate that expertise is a level of proficiency that is achievable by novices, and the goal is to gain an understanding of how less skilled or less experienced individuals become more skilled (Chi 2006). However, stage models have been criticised for 'not being able to explain how the development from novice to expert comes about, that is, how learning takes place' (Tynjälä 1999, 360) and for providing 'little information on how an individual transitions from one stage to the next or what occurs after initial expertise is achieved' (Grenier and Kehrhahn 2008, 202). Scholars have called for a more learning-based focus in expertise research (Jung, Minkyoung, and Reigeluth 2016; Tynjälä 1999).

\section{How do experts learn?}

A substantial amount of previous research suggests that expertise development takes at least 
ten years of practice. Expertise or excellent performance is based on a large domain-specific base and cognitive skills. (Ericsson, Krampe, and Tesch-Römer 1993; Van der Heijden 2002.) Learning theories describing expertise development describe both the learner's individual mental activities and the social contexts of learning. In the context of adult learning, in particular, learning theories focus on an individual's self-directed learning (Knowles 1975). When learning is self-directed, the learner takes the initiative to formulate and pursue learning goals as well as complete and evaluate their learning. Merriam (2001) states that one goal of self-directed learning is to foster transformative learning, which underlines the importance of critical reflection in challenging the taken-for-granted perceptions of the world and everyday life.

Socio-cultural approaches to learning emphasise the social and cultural contexts in which learning occurs. Lave and Wenger (1991) describe learning as a process of social participation, in which novices move from legitimate peripheral participation and less critical work tasks towards gradually deepening participation and eventually full membership in the communities of practice (Wenger 1998). Expertise develops as novices are acculturated into the communities of practice and as they closely interact with other experts. Recent learning theories have also noted the collaborative nature and meaning of knowledge creation in learning. Accordingly, Engeström's (2004) concept of expansive learning includes the aspect of critical reflection of former practices and the construction and creation of new knowledge. Engeström (2004) states that expertise is not only located in communities of practice, but also in multiple interacting communities. 'Knotworking' refers to collaborations between otherwise loosely connected actors and organisations, who come together to negotiate meanings and solve problems. Network learning not only implies individuals and organisations learning in networks, but also refers to processes through which the network itself transforms its ways of thinking and learning (Knight 2002; Tynjälä 2008). 
Whether the emphasis is on the individual learner or the social contexts of learning, central to the development of expertise and expert learning is the integration of the different elements of expertise (Leinhardt McCarthy, and Merriman 1995; Le Maistre and Pare 2006; Tynjälä 1999, 2008). Tynjälä’s model of integrative pedagogy highlights the importance of integrating the 'key elements of expertise - that is, theory, practice and self-regulation' $(2008,144)$. Theoretical or conceptual knowledge consists of universal and formal knowledge that can easily be explicated, whereas practical knowledge gained through experiences is case-specific, intuitive, implicit or tacit in nature (Tynjälä 2008). Bereiter and Scardamalia (1993) state that problem solving forms a natural platform for the integration of different forms of expert knowledge. According to Bereiter and Scardamalia $(1993,66)$, "formal knowledge is converted into skill by being used to solve problems of procedure" and "formal knowledge is converted into informal knowledge by being used to solve problems of understanding". Progressive problem solving refers to experts constantly working at the edge of their competence, solving increasingly complex problems and thus developing their expertise.

Hytönen et al. (2016) have integrated many of the above-mentioned approaches and defined a concept of 'adaptive expertise'. It refers to 'a professional's personal efforts aimed at deliberately improving his or her professional competence, seeking alternative solutions for existing professional practices and becoming an active knowledge-building and networking actor in his or her professional field in order to reach the highest levels of professional competence' (336). Adaptive experts should have strong self-regulative skills (Zimmerman 2000), as the highest level of expert performance requires self-regulation and reflection on evolving professional competences (Nokelainen, Kaisvuo, and Pylväs 2017). 


\section{Method}

Using an integrative approach (Torraco 2005; Whittemore and Knafl 2005), we combined different methodologies to review literature and summarise it for a more comprehensive understanding of the phenomenon. Integrative literature reviews are the broadest type of research review methods and they are distinctive for combining diverse data sources, such as experimental and non-experimental research or theoretical and empirical literature. The purpose of an integrative review is to provide a holistic understanding of the topic of interest, that can be for example defining a concept, review of a theory or examination of methodological issues. (Whittemore and Knafl 2005.) Authors of an integrative literature review are supposed to review, critique, and synthesize "representative literature on a topic in an integrated way such that new frameworks and perspectives on the topic are generated" (Torraco 2005, 356). An integrative literature review entails problem identification, formulation of inclusion and exclusion criteria, literature research and finally the evaluation and analysis of data (Whittemore and Knafl 2005). We have described our problem and research questions previously in the introduction and in this section we will describe the other phases of the review process.

\section{Literature research}

An electronic database search was conducted in April-May 2016 using a variety of internet search engines: Educational Resources Information Centre (ERIC), SCOPUS, PsychINFO and EBSCOhost. We also performed a complementary search on Google Scholar and crossreferenced articles found in the search. Many search terms were used to find the studies included in the review, and the scope of the terms ranged from more general (e.g., expertise) to more specific (e.g., work-based learning, higher education). The different search terms and phases of the literature research process are presented in Figure 1. 


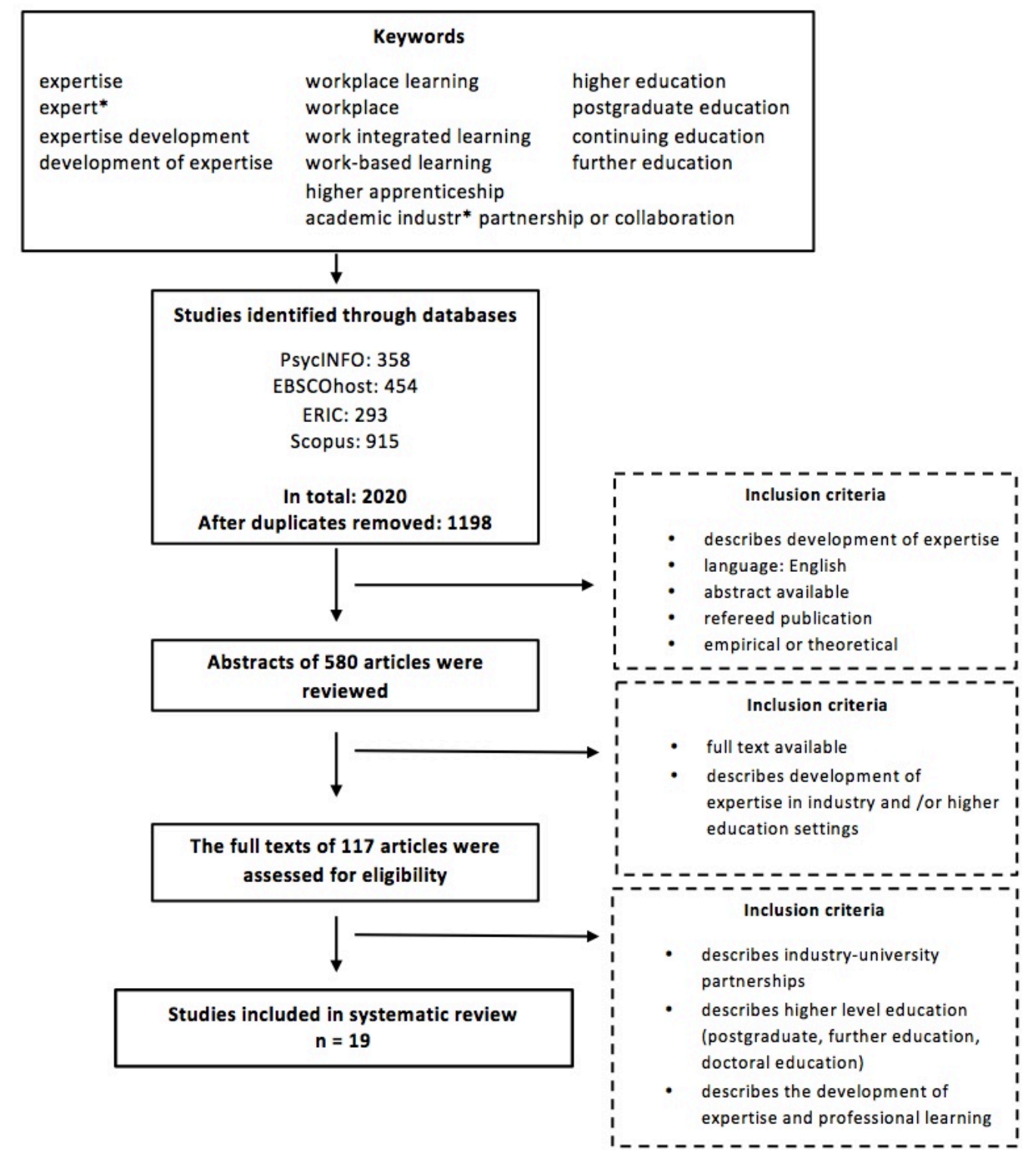

Figure 1. Design of the literature review.

The search yielded 2020 studies. After removing duplicates, we were left with 1198 studies. The references to these works were saved in ab electronic format and moved to RefWorks. During the first stage of the literature review, the titles and abstracts of the studies were examined and those that did not meet the search criteria were eliminated. We narrowed the corpus based on the following inclusion criteria: the study (1) describes the development of expertise, (2) is written in English, (3) has an abstract available, (4) is refereed, (5) covers empirical or theoretical work. The analysis resulted in 580 studies that were assessed in the 
second stage with the following inclusion criteria: (6) describes the development of expertise in industry or/and higher education settings, (7) is available in full text format. A total of 117 full texts met the inclusion criteria described above. In the third stage, we included only studies that described (8) industry-university partnerships, (9) higher level education, and (10) the development of expertise or professional learning. Finally, 19 studies that matched our criteria were finalised for the literature review.

\section{Summary of included studies}

Table 1 provides an overview of the 19 studies $(2003-2016)$ included in the review. Of the 19 studies, 13 were empirical and 6 were conceptual contributions. All the empirical studies used qualitative data collection methods, mostly different types of interviews (semistructured, open-ended and group interviews). Three of these studies also used quantitative methods (two used descriptive and one used multivariate statistics). The total number of participants in the 13 empirical studies was 1054. The qualitative studies had 7 to 33 participants, and the quantitative studies had 85 to 409 participants. Three studies used longitudinal design, and the remaining nine were cross-sectional. Voluntary participation and participants' gender distribution were reported in nine out of 13 studies. The methodological quality of all 13 empirical articles was evaluated using the Critical Appraisal Skills Programme (CASP 2014) checklist. Nine articles score high on the ratings, and the remaining four received medium ratings. The 19 studies included in this review were mostly published in multidisciplinary domains (8), the domains of medicine (3), teacher education (3) and business (2). Other domains (occupational risk management, police training, public works) were mentioned once. The topics of the studies included professional doctorates (7), postgraduate education (4), work-based higher education (4), further education (3) and higher education professional training (1). The studies were mainly conducted in Europe, mostly in 
the UK (13) but also in Finland (3) and Germany (1). Studies were also conducted in Australia (2), China (1) and Canada (1). 
Table 1. Details of the included studies

\begin{tabular}{|c|c|c|c|c|c|c|c|c|}
\hline Author(s) & Country & $\begin{array}{l}\text { Type of } \\
\text { publication }\end{array}$ & Research methods & Purpose & $\begin{array}{l}\text { Data collection methods } \\
\text { and sample }\end{array}$ & Domain & $\begin{array}{l}\text { Educational } \\
\text { field }\end{array}$ & $\begin{array}{l}\text { CASP } \\
\text { rating }\end{array}$ \\
\hline $\begin{array}{l}\text { Armsby } \\
2013\end{array}$ & UK & Empirical & Qualitative & $\begin{array}{l}\text { Explores how } \\
\text { professional learning } \\
\text { and identity may be } \\
\text { developed through the } \\
\text { recognition of } \\
\text { experiential learning in } \\
\text { professional doctorate } \\
\text { education. }\end{array}$ & $\begin{array}{l}\text { Semi-structured telephone } \\
\text { interviews, questionnaires, } \\
\text { focus group and participant } \\
\text { observation methods were } \\
\text { employed with students and } \\
\text { staff involved with their own } \\
\text { learning, teaching and } \\
\text { assessment process }(N=32) \text {. }\end{array}$ & Public works & $\begin{array}{l}\text { Professional } \\
\text { doctorate }\end{array}$ & High \\
\hline $\begin{array}{l}\text { Beighton } \\
\text { and Poma } \\
2015\end{array}$ & UK & Empirical & Qualitative & $\begin{array}{l}\text { Examines the } \\
\text { developing relationship } \\
\text { between higher } \\
\text { education practices and } \\
\text { professional training } \\
\text { for UK firearms } \\
\text { officers. }\end{array}$ & $\begin{array}{l}\text { Qualitative semi-structured } \\
\text { interviews with officers from } \\
\text { three UK forces }(N=7) \text {. }\end{array}$ & Police training & $\begin{array}{l}\text { Higher } \\
\text { education } \\
\text { professional } \\
\text { training }\end{array}$ & High \\
\hline $\begin{array}{l}\text { Chivers } \\
2007\end{array}$ & UK & Empirical & Qualitative & $\begin{array}{l}\text { Determines how } \\
\text { postgraduate study in } \\
\text { vocational fields } \\
\text { supports the } \\
\text { development of } \\
\text { advanced competences } \\
\text { amongst mid-career } \\
\text { professionals. }\end{array}$ & $\begin{array}{l}\text { Written communications ( } N \\
=66, \text { e-mail reports, queries, } \\
\text { drafts of written work with } \\
\text { notes, feedback forms) } \\
\text { between students and their } \\
\text { tutor. }\end{array}$ & $\begin{array}{l}\text { Occupational } \\
\text { risk management }\end{array}$ & $\begin{array}{l}\text { Postgraduate } \\
\text { education }\end{array}$ & High \\
\hline $\begin{array}{l}\text { Costley and } \\
\text { Lester } 2012\end{array}$ & UK & Conceptual & - & $\begin{array}{l}\text { Discussion on the } \\
\text { nature of work-based } \\
\text { doctorates. }\end{array}$ & Literature review. & Multidisciplinary & $\begin{array}{l}\text { Professional } \\
\text { doctorate }\end{array}$ & \\
\hline $\begin{array}{l}\text { Costley } \\
2010\end{array}$ & UK & Empirical & Qualitative & $\begin{array}{l}\text { Examines the learning } \\
\text { that influenced } \\
\text { personal and } \\
\text { organisational change } \\
\text { brought about by a } \\
\text { professional doctorate }\end{array}$ & $\begin{array}{l}\text { Open-ended interviews }(N= \\
10) .\end{array}$ & Multidisciplinary & $\begin{array}{l}\text { Professional } \\
\text { doctorate }\end{array}$ & High \\
\hline
\end{tabular}




\begin{tabular}{|c|c|c|c|c|c|c|c|c|}
\hline & & & & programme. & & & & \\
\hline $\begin{array}{l}\text { Costley } \\
2013\end{array}$ & $\begin{array}{l}\text { UK and } \\
\text { Australia }\end{array}$ & Empirical & Qualitative/quantitative & $\begin{array}{l}\text { Examines the status } \\
\text { and knowledge } \\
\text { contributions of } \\
\text { professional doctorates } \\
\text { (PDs) undertaken by } \\
\text { practising } \\
\text { professionals, most of } \\
\text { whom did not intend to } \\
\text { join the academic } \\
\text { community. }\end{array}$ & $\begin{array}{l}\text { A survey to map information } \\
\text { for an interview schedule. } \\
\text { Interviews with (1) } \\
\text { coordinators, academic and } \\
\text { industry supervisors and } \\
\text { examiners; and (2) graduates } \\
\text { about their experiences of } \\
\text { doctoral programmes. Focus } \\
\text { group interviews were } \\
\text { conducted with some } \\
\text { students. } \\
\text { The sample }(N=283) \\
\text { included comparisons } \\
\text { between } 147 \text { PDs and } 136 \\
\text { PhDs. }\end{array}$ & Multidisciplinary & $\begin{array}{l}\text { Professional } \\
\text { doctorate }\end{array}$ & Medium \\
\hline Finlay 2008 & UK & Empirical & Qualitative & $\begin{array}{l}\text { Reports on a research } \\
\text { project that sought to } \\
\text { gain a deeper } \\
\text { understanding of } \\
\text { universities' } \\
\text { contribution to the } \\
\text { professional learning } \\
\text { of teachers. }\end{array}$ & $\begin{array}{l}\text { Final assignments }(N=26) \\
\text { produced by students. }\end{array}$ & $\begin{array}{l}\text { Teacher } \\
\text { education }\end{array}$ & $\begin{array}{l}\text { Further } \\
\text { education }\end{array}$ & High \\
\hline $\begin{array}{l}\text { Hay and } \\
\text { Samra- } \\
\text { Fredericks } \\
2016\end{array}$ & UK & Empirical & Qualitative & $\begin{array}{l}\text { Explores the } \\
\text { experiences of } \\
\text { practitioners enrolled } \\
\text { in a UK Doctor of } \\
\text { Business } \\
\text { Administration (DBA) } \\
\text { programme and on } \\
\text { their way to becoming } \\
\text { researchers. }\end{array}$ & Reflective diaries $(N=20)$. & $\begin{array}{l}\text { Business } \\
\text { (administration) }\end{array}$ & $\begin{array}{l}\text { Professional } \\
\text { doctorate }\end{array}$ & High \\
\hline Lester and & UK & Conceptual & - & Discussion about & Literature review. & Multidisciplinary & Work-based & \\
\hline
\end{tabular}




\begin{tabular}{|c|c|c|c|c|c|c|c|c|}
\hline $\begin{array}{l}\text { Costley } \\
2010 \\
\end{array}$ & & & & $\begin{array}{l}\text { higher education and } \\
\text { work-based learning. }\end{array}$ & & & $\begin{array}{l}\text { higher } \\
\text { education }\end{array}$ & \\
\hline Lucas 2007 & UK & Conceptual & - & $\begin{array}{l}\text { Critiques the initial } \\
\text { teacher education } \\
\text { (ITE) of further and } \\
\text { adult education } \\
\text { teachers in the UK. }\end{array}$ & Literature review. & $\begin{array}{l}\text { Teacher } \\
\text { education }\end{array}$ & $\begin{array}{l}\text { Further } \\
\text { education }\end{array}$ & \\
\hline $\begin{array}{l}\text { Lucas and } \\
\text { Unwin } 2009\end{array}$ & UK & Empirical & Qualitative/quantitative & $\begin{array}{l}\text { Presents findings from } \\
\text { a study of the } \\
\text { experiences of in- } \\
\text { service trainee teachers } \\
\text { in colleges of further } \\
\text { education in England. }\end{array}$ & $\begin{array}{l}\text { Questionnaire survey }(N= \\
409) \text { of in-service trainee } \\
\text { teachers. Semi-structured } \\
\text { telephone interviews }(n=21) \\
\text { and learning logs }(n=22) .\end{array}$ & $\begin{array}{l}\text { Teacher } \\
\text { education }\end{array}$ & $\begin{array}{l}\text { Further } \\
\text { education }\end{array}$ & Medium \\
\hline $\begin{array}{l}\text { Mylopoulos, } \\
\text { Regehr, and } \\
\text { Ginsburg } \\
2011\end{array}$ & Canada & Empirical & Qualitative & $\begin{array}{l}\text { Explores how residents } \\
\text { at the postgraduate } \\
\text { level of training } \\
\text { conceptualise } \\
\text { expertise, expert } \\
\text { development, and their } \\
\text { own learning in the } \\
\text { developing expert } \\
\text { trajectory. }\end{array}$ & $\begin{array}{l}\text { Semi-structured interviews } \\
(N=33) \text { with postgraduate } \\
\text { students. }\end{array}$ & Medicine & $\begin{array}{l}\text { Postgraduate } \\
\text { education }\end{array}$ & High \\
\hline Petty 2015 & UK & Conceptual & - & $\begin{array}{l}\text { Explores how } \\
\text { practitioners may } \\
\text { develop clinical } \\
\text { expertise. }\end{array}$ & Literature review. & $\begin{array}{l}\text { Medicine } \\
\text { (Osteopathy) }\end{array}$ & $\begin{array}{l}\text { Postgraduate } \\
\text { education }\end{array}$ & \\
\hline Sense 2016 & Australia & Empirical & Qualitative & $\begin{array}{l}\text { Examines structure and } \\
\text { processes of a work- } \\
\text { based research degree } \\
\text { programme engaging a } \\
\text { cohort of industry } \\
\text { partners with a } \\
\text { university in } \\
\text { promoting and } \\
\text { supporting those } \\
\text { degrees. }\end{array}$ & $\begin{array}{l}\text { A case study with semi- } \\
\text { structured primary } \\
\text { stakeholder }(N=20) \\
\text { interviews, observations and } \\
\text { documentation analysis. }\end{array}$ & Multidisciplinary & $\begin{array}{l}\text { Professional } \\
\text { doctorate }\end{array}$ & Medium \\
\hline $\begin{array}{l}\text { Slotte and } \\
\text { Tynjälä }\end{array}$ & $\begin{array}{l}\text { Finland } \\
\text { and }\end{array}$ & Empirical & Qualitative & $\begin{array}{l}\text { Examines industry- } \\
\text { university cooperation }\end{array}$ & $\begin{array}{l}\text { Three group interviews and } \\
\text { individual one-hour meetings }\end{array}$ & $\begin{array}{l}\text { Business } \\
\text { (Human resource }\end{array}$ & $\begin{array}{l}\text { Work-based } \\
\text { higher }\end{array}$ & Medium \\
\hline
\end{tabular}




\begin{tabular}{|c|c|c|c|c|c|c|c|c|}
\hline 2003 & China & & & $\begin{array}{l}\text { as a vehicle for } \\
\text { learning and the } \\
\text { development of } \\
\text { expertise for those who } \\
\text { work as professionals } \\
\text { in companies and } \\
\text { organisations. }\end{array}$ & $\begin{array}{l}(N=17) \text { with students. In } \\
\text { addition, all the messages } \\
\text { exchanged on the discussion } \\
\text { forum formed a database that } \\
\text { was used to complement the } \\
\text { results. }\end{array}$ & development) & education & \\
\hline $\begin{array}{l}\text { Stephenson, } \\
\text { Malloch, } \\
\text { and Cairns } \\
2006\end{array}$ & UK & Empirical & Qualitative & $\begin{array}{l}\text { Examines the learning } \\
\text { experiences of } \\
\text { professional doctorate } \\
\text { graduates. }\end{array}$ & $\begin{array}{l}\text { Open-ended interviews with } \\
\text { graduates }(N=10) .\end{array}$ & Multidisciplinary & $\begin{array}{l}\text { Professional } \\
\text { doctorate }\end{array}$ & High \\
\hline $\begin{array}{l}\text { Tynjälä } \\
2008\end{array}$ & Finland & Conceptual & - & $\begin{array}{l}\text { Discusses learning at } \\
\text { work and workplace } \\
\text { learning that is related } \\
\text { to formal education. }\end{array}$ & Literature review. & Multidisciplinary & $\begin{array}{l}\text { Work-based } \\
\text { higher } \\
\text { education }\end{array}$ & \\
\hline $\begin{array}{l}\text { Tynjälä, } \\
\text { Välimaa, } \\
\text { and Sarja } \\
2003\end{array}$ & Finland & Conceptual & - & $\begin{array}{l}\text { Examines the } \\
\text { pedagogical aspects of } \\
\text { the increasing } \\
\text { interaction and } \\
\text { collaboration between } \\
\text { higher education and } \\
\text { working life and } \\
\text { outlines what kind of } \\
\text { challenges it poses for } \\
\text { research on higher } \\
\text { education. }\end{array}$ & Literature review. & Multidisciplinary & $\begin{array}{l}\text { Work-based } \\
\text { higher } \\
\text { education }\end{array}$ & \\
\hline $\begin{array}{l}\text { Vollmer, } \\
\text { Spada, } \\
\text { Caspar, and } \\
\text { Burri } 2013\end{array}$ & Germany & Empirical & Qualitative/quantitative & $\begin{array}{l}\text { Examines how } \\
\text { university training and } \\
\text { subsequent practical } \\
\text { experience affect } \\
\text { expertise in clinical } \\
\text { psychology. }\end{array}$ & $\begin{array}{l}\text { Multiple-choice questions, } \\
\text { open-format questions and } \\
\text { case studies }(N=100)\end{array}$ & $\begin{array}{l}\text { Medicine } \\
\text { (Clinical } \\
\text { psychology and } \\
\text { psychotherapy) }\end{array}$ & $\begin{array}{l}\text { Postgraduate } \\
\text { education }\end{array}$ & High \\
\hline
\end{tabular}




\section{Data evaluation and analysis}

We read all the articles and summarised each study's purpose, domain, educational field, sample and data collection methods. We conducted the analysis according to the principles of qualitative data analysis (Miles and Huberman 1994) and by utilising the guidelines for analysing data in integrative reviews (Torraco 2005; Whittemore and Knafl 2005). We used the NVIVO (version 10.2.2) to assist with the analysis.

In the first phase, we focused on the extracts that described the factors contributing to expertise development and that described the different factors that support or challenge expertise development and learning during WBHE. In the second phase, we inductively coded and compared these extracts to identify patterns and relationships. The third phase involved synthesising resulting patterns and relationships into categories that reflect the central elements of expert learning in WBHE.

\section{Findings}

Analysis of the 19 included studies resulted in five central elements of expert learning in WBHE: (1) knowledge transformation and integration, (2) problem solving, (3) reflection, (4) learning from errors and (5) boundary crossing (Figure 2). Review of the studies show that knowledge transformation and integration is at the heart of expertise development in WBHE, but also four other main elements describe key components in this developmental process via different aspects. Next we describe the contents of these interrelated elements in detail. 


\begin{tabular}{|c|c|}
\hline $\begin{array}{l}\text { Problem solving } \\
\text { Introducing non-routine and practical problems } \\
\text { Challenging to solve problems collaboratively } \\
\text { Encouraging learners to acknowledge and solve } \\
\text { professional identity issues }\end{array}$ & $\begin{array}{l}\text { Reflection } \\
\text { Stimulating critical reflection on learning and experiences } \\
\text { Encouraging reconstruction of the meaning of } \\
\text { experiences } \\
\text { Promoting responsive guidance through mentoring }\end{array}$ \\
\hline \multicolumn{2}{|c|}{$\begin{array}{l}\text { Knowledge transformation and integration } \\
\text { Integrating workplace learning with academic studies } \\
\text { ansforming experience to expertise through deliberate practice } \\
\text { cturing workplace learning opportunities and relating formal and } \\
\text { informal learning } \\
\text { Developing self-regulative and metacognitive knowledge }\end{array}$} \\
\hline $\begin{array}{l}\text { Learning from errors } \\
\text { Helping learners to resolve tensions and develop flexible } \\
\text { imagining } \\
\text { Promoting epistemic processes to help identify flaws in } \\
\text { one's mental models } \\
\text { Developing learners' time and resource management } \\
\text { Promoting critical dialogue through collaboration and } \\
\text { mentoring }\end{array}$ & $\begin{array}{l}\text { Boundary crossing } \\
\text { Developing learner identity and adaptation } \\
\text { Creating multiple opportunities for participation and } \\
\text { learning } \\
\text { Retaining university and workplace perspectives } \\
\text { Explicating cyclical expertise development process } \\
\text { between work and academic contexts }\end{array}$ \\
\hline
\end{tabular}

Figure 2. Central elements of expert learning in work-based higher education.

\section{Knowledge transformation and integration as the key to expertise development}

Consistent with earlier research on expertise, the reviewed articles identified the process of transforming theoretical knowledge into practice and conceptualising practical or experiential knowledge as the key to expertise development in WBHE. The articles highlighted that the role of the university is to offer conceptual resources, such as theoretical frameworks that can be supported by conceptual tools, such as learning journals. The studies highlighted the importance of conceptual tools to 'master complicated ideas' (Slotte and Tynjälä 2003) and illustrated how theoretical understanding could be used to understand aspects of practise (Finlay 2008). However, a challenge in WBHE is that the programmes include too much academic knowledge, which makes it difficult for learners and workplaces 
to see the connection between studying and the needs at work. Providing merely theoretical knowledge is therefore not enough; learning tasks and theoretical knowledge should be linked to authentic and practical work situations (Slotte and Tynjälä 2003).

Likewise, Vollmer et al. (2013) in their study on expertise development in clinical psychology found that experience does not automatically translate into expertise; it requires a substantial amount of deliberate practice. Therefore, combining standardised university studies with theory-based practical training can support expertise development. Additionally, Chivers (2007) found that on-the-job learning alone or other informal learning gained by professionals does not necessarily develop their meta-competences and higher cognitive competences to the highest levels. Work-based learning should be seen as more than a process of learning by doing; universities should formulate a 'pedagogy of the workplace', i.e. an intentional structuring that plans the learning opportunities in the workplace and guides the learners to relate formal and informal learning (Lucas 2007; Slotte and Tynjälä 2003; see also Guile and Griffiths 2001).

In addition to integrating theoretical and practical knowledge, the review highlighted the importance of supporting the learners' development of self-regulative and metacognitive knowledge (e.g., Chivers 2007; Costley 2010; Slotte and Tynjälä 2003; Stephenson, Malloch, and Cairns 2006; Tynjälä, Välimaa, and Sarja 2003). The learners in WBHE are already considered as experts within their own professional field and may possess a substantial amount of professional and subject-based knowledge. Certain features of learning, such as learner autonomy, self-management, agency and individual development may significantly support their development of professional expertise (e.g., Costley 2010; Stephenson, Malloch, and Cairns 2006). According to Stephenson, Malloch, and Cairns (2006), learners benefit considerably from self-examination and managing their learning themselves; these entail building 'personalized programmes around their distinctive previous professional 
experience, current professional issues and longer term professional plans' (Stephenson, Malloch, and Cairns 2006, 19) and perceiving themselves as 'the principal agent of control of a programme situated within critical and demanding academic and professional contexts' (Stephenson, Malloch, and Cairns 2006, 26).

\section{Problem solving}

In line with previous research, the reviewed articles emphasised 'problem solving as a mediating tool for the integration of different components of expert knowledge' (Slotte and Tynjälä 2003, 452; see also Tynjälä, Välimaa, and Sarja 2003; Tynjälä 2008). This implies that when educating skilled workforce, problem-solving tasks should form the core of the education (Tynjälä 2008).

In particular, solving ill-defined or non-routine problems - problems that do not have just one correct solution and require several factors to be considered simultaneouslyimproves the capabilities and the intellectual capacity of skilled workers/students (Mylopoulos, Regehr, and Ginsburg 2011; Slotte and Tynjälä 2003). Mylopoulos, Regehr, and Ginsburg (2011) found that transforming problems from non-routine to routine was achieved by solving practical problems and by gaining practical experience. During the routinisation process, participants acquired an increased understanding of how their physical and social environments affected their decisions and problem-solving processes. They moved beyond simple recognition of routine diagnostic cases to focusing on how to best manage the problems with the given resources: 'It's like knowledge but it's knowledge of resources as opposed to knowledge of diagnosis or prognosis' (Mylopoulos, Regehr, and Ginsburg 2011, 48).

Today experts operate in constantly changing conditions, which requires them to adapt to new situations and challenges and forces them back into development modes 
(Grenier and Kehrhahn 2008). Therefore, even though routinisation is a necessary process when developing expertise, acknowledging that non-routine problems are a vital part of professionals' daily practice is needed for the development and maintenance of expertise. This requires a change in the approach towards non-routine problems, so that non-routine problem solving is conceptualised as an 'ongoing, iterative process rather than as an instance of "having the answer"' (Mylopoulos, Regehr, and Ginsburg 2011, 48).

I think the other thing I've realized is that a lot of nonroutine problems, I don't have to completely solve or fix overnight. There's usually an iterative process of starting something and re-evaluating what you've done and seeing if it worked and if it didn't maybe go down a different path and if it did, then your initial hypothesis is right and you can move on. So I think it's a structure, thinking of it as a process, rather than a single problem. And it included a process of avoiding prematurely narrowing their problem space by fitting problems to existing solutions (Mylopoulos, Regehr, and Ginsburg 2011, 48).

Slotte and Tynjälä (2003) add that the development of adaptive expertise demands that problems are examined in interaction with others. In collaborative learning, learners should be interdependent knowledge-wise, i.e. they need each other to accomplish a task. Further, learners are required to build a common ground, develop mutual understanding and trust in each other - all of which calls for the acquisition of new learning skills. Sense (2016, 951) notes that creating and facilitating connections between students, their colleagues and the academic staff promotes social learning, which in turn 'assists the formal and informal learning development of candidates and the knowledge dissemination around the network'. 
Problem solving does not solely refer to solving issues related to practical or workrelated problems; it also involves solving problems and issues related to professional identity. During a WBHE programme, not only do the participants develop their knowledge base and professional competences by solving authentic real-life problems, they also develop their professional personalities and solve different identity issues that arise (e.g., Armsby 2013; Sense 2016; Stephenson, Malloch, and Cairns 2006).

\section{Reflection}

Armsby's (2013) study reported that the major reasons candidates enrolled in a workbased doctoral programme were to achieve the doctoral status and have their work evaluated and accredited. However, interestingly, during the programme, these instrumental values changed, and the candidates started to appreciate the opportunity to analyse and reflect on their experiences. The participants noted that 'the developmental aspect of the process was the most important characteristic of the programme' (Armsby 2013, 420).

They got a lot out of delving into what they'd done and pulling it all together and making sense of it and doing that sort of looking back and reconstructing things in the light of what you know now, kind of thing. So that made the exercise itself valuable to the people so they weren't just demonstrating what they'd done before ... (Adviser) (Armsby 2013, 423).

The shift from a credentialing mentality towards a developmental philosophy was achieved by offering the candidates opportunities to critically reflect on their professional contribution and impact and by providing them with the time and opportunities to reconstruct the meaning of their experiences and more widely reflect on their professional identity (Armsby 2013; see also Finlay 2008; Hay and Samra-Fredericks 2016; Sense 2016; Stephenson, Malloch, and Cairns 2006). 
The articles highlighted that reflecting on their experiences and learning, for instance during oral examinations (Armsby 2013) or through keeping a learning journal (Finlay 2008; Hay and Samra-Fredericks 2016; Tynjälä, Välimaa, and Sarja 2003), not only helps the candidates make sense of their professional and personal development (Armsby 2013; Costley 2013; Finlay 2008; Hay and Samra-Fredericks 2016; Tynjälä, Välimaa, and Sarja 2003) but also aids in putting theory to practice (Finlay 2008). According to Stephenson, Malloch, and Cairns (2006, 23), 'reflection on previous experience, current activities, wider professional involvement and the level of achievement are key ways in which capability is enhanced.'

However, Chivers (2007) notes that merely on-the-job learning and other informal and incidental learning without the integration with university-level studies is not enough to develop the professionals' meta-competences and cognitive professional competences to the highest levels. He notes, 'learning only by reflection on practice will be as limited in scope as the extent of that practice, and as limited in depth as the extent of that reflection' (657). In line with this view, Vollmer et al. (2013) found that in-service behaviour therapists with more than 10 years of clinical experience were outperformed by psychology students and trainees in a certified postgraduate psychotherapist curriculum. They explained that this was due to the behaviour therapists' inability to identify (self-assess) areas of further education needed to keep up with recent developments in their field.

The role of advisors and teachers is to provide support, guidance and encouragement so that the candidates can reflect and view their work from different perspectives, conceptualise their experiences and examine theoretical knowledge in light of practical work (Armsby 2013; Chivers 2007; Stephenson, Malloch, and Cairns 2006; Tynjälä, Välimaa, and Sarja 2003). It is also noteworthy, that in WBHE, the learner's expertise may be greater than anyone else's in the institution, whereupon 'the traditional role of discipline-based supervisor 
to whom the candidate is in a sense an academic apprentice is unlikely to be appropriate' (Costley and Lester 2012, 262). For learning to occur, the academic staff should function more as advisors or mentors and less as expert supervisors (Lester and Costley 2010). Sense $(2016,950)$ refers to this as guidance 'at an arms-length', which allows students to respect their own abilities and grow in confidence as experts in the academic field. A study by Stephenson, Malloch, and Cairns (2006) also endorses the importance of tutors being responsive to learners' initiatives and suggestions as well as being available whenever the learners need help.

\section{Learning from errors}

Errors, or as Finlay $(2008,78)$ describes, ‘difficult, conflictual or paradoxical situations' were quoted in several articles as key factors of expertise development and learning (Beighton and Poma 2015; Finlay 2008; Hay and Samra-Fredericks 2016; Petty 2015; Slotte and Tynjälä 2003). Learning from mistakes or contradictory experiences requires learners to resolve tensions and develop flexible imagining, which pushes them to broaden their expertise, as reported in previous studies on incidental learning in the workplace (e.g., Cannon and Edmondson 2005; Eraut 2004). Learning from failures motivates epistemic processes like hypothesis generation and information gathering, and helps identify flaws in mental models (Ellis and Davidi 2005). Jung, Minkyoung, and Reigeluth (2016) argue that proficient learners have a stronger tendency to learn from failures than inexperienced learners and experts endure 'a wide variety of tough cases, challenges that have enriched their knowledge models' (Jung, Minkyoung, and Reigeluth 2016, 59).

Hay and Samra-Fredericks (2016) found that students encounter threshold concepts, defined as "places in the curriculum where students get stuck, but when grasped allow students to access new understandings. They can be likened to a "gateway" through which a 
student must pass in order to progress' (Hay and Samra-Fredericks 2016, 5). Threshold concepts, like errors, are troublesome, integrative, bounded, irreversible and transformative. They are both troublesome, associated with unsettling feelings such as confusion, doubt and frustration, and transformative, since they tend to shift the students' perceptions and actions. (Hay and Samra-Fredericks 2016; see also Hibbert and Cunliffe 2015; Wright and Gilmore 2012.) For example, unfamiliar concepts such as research methodology or incoherence between identities evoke feelings of being lost:

The most interesting experience was when I submitted Document 3 ... marked as a fail. How could this be? My world collapsed as I had never had a fail in my whole career and I thought it was the end (Hay and SamraFredericks 2016, 8-9).

Several articles identified lack of time and time management issues as difficulties and conflictual situations experienced during studies. Learners struggled with balancing work and studies, and often did not receive any remission from the hours they spent studying and at the university (Finlay 2008; Hay and Samra-Fredericks 2016; Lucas and Unwin 2009; Sense 2016; Slotte and Tynjälä 2003). Many identified this as the reason for not excelling in their studies (Finlay 2008; Lucas and Unwin 2009; Slotte and Tynjälä 2003).

The social support gained from supervisors and fellow students is important when learners are coping with different kind of errors and difficult situations during their studies. Camaraderie with fellow students provides a feeling of togetherness and encourages the students to continue with their studies. Similarly, the guidance of supervisors helps students cope with feelings of uncertainty and discomfort and facilitates progress (Hay and SamraFredericks 2016). However, mentor may facilitate the development of expertise also by providing critical comments on practice, which 'creates opportunities for individuals to experience contradiction that may trigger learning' (Petty 2015, 214). The role of the mentor 
is to challenge taken-for-granted assumptions and question the learner's knowledge.

Reflection triggered by errors is considered a useful way to develop flexible imagining and the responsibility needed in practice, instead of doing things in a pre-codified way (Beighton and Poma 2015).

\section{Boundary crossing}

Boundary crossing refers to the need of professionals to enter unfamiliar territories and to 'face the challenge of negotiating and combining ingredients from different contexts to achieve hybrid situations' (Engeström, Engeström, and Kärkkäinen 1995, 319; see also Akkerman and Backer 2011). The reviewed articles explained how the students occupy an inbetween space - they move back and forth between two contexts: the unfamiliar university and the familiar workplace. This kind of boundary crossing and moving out of their base activity system (workplace) results in a change of identity and helps the student expand their perspectives and develop their work practices (Finlay 2008; Hay and Samra-Fredericks 2016; Stephenson, Malloch, and Cairns 2006).

However, it is worth noting that not all workplaces are ideal learning environments as they can be disempowering and trap the learner into an employer-driven or instrumental agenda (Lester and Costley 2010). When crossing boundaries between the university and the workplace, knowledge transformation and integration is best achieved when the university retains its critical perspective, and the workplace offers a 'real time' and 'real world' perspective (Costley 2013; Lester and Costley 2010). Adaptation is needed on the part of the learner, the workplace and the university because 'professional values and practices cannot be simply imported from one context to another, since contexts and practices are both open to change' (Beighton and Poma 2015, 194). Thus, in order to develop as experts, professionals are required to adapt to new situations instead of reproducing practiced operations regardless 
of context (e.g., Beighton and Poma 2015; Costley 2013; see also Grenier and Kehrhahn 2008).

The students in WBHE typically have a wide variety of work experience and qualifications. The diversity of backgrounds in turn implies that students have multiple learning needs and require different levels of participatory experiences, feedback and support. Thus, instead of mapping learning to a set of national standards, the emphasis should be placed on multiple opportunities for participation and learning according to individual needs. (Lucas 2007; see also Stephenson, Malloch, and Cairns 2006.) Sense (2016) also notes that the students' prior knowledge and experience in the industry should also be acknowledged and respected, as it serves as a starting point for them to theoretically explore their work.

Despite their wide variety of work experience and feelings of high competence in the workplace, students in WBHE may feel less confident and competent in a university setting. Compared to full-time university students who often step away from their earlier lives to enrol in a programme, students in WBHE shuttle between the contexts of the classroom, the workplace and home. As a result, they struggle with feelings of identity incoherence as they constantly negotiate their identities during the studies. Therefore, crossing boundaries and 'liminal spaces' cannot be described as a linear movement between different phases, but rather as a continuous process (Hay and Samra-Fredericks 2016). This requires a reconceptualisation of traditional linear stage models of expertise development to acknowledge that 'expertise development is not a finite process with a single end point, but instead it is a fluid, cyclical process founded on continuous exploration, experimentation, and learning' (Grenier and Kehrhahn 2008, 205).

\section{Discussion and conclusion}

The purpose of this review was to examine how experienced professionals develop their 
expertise during WBHE. The findings describe how WBHE can contribute to the development of professional expertise and higher level of learning. Consistent with earlier research on expertise and professional learning (e.g., Cheetham and Chivers 2001; Elvira et al. 2016; Grenier 2009), our review confirms that expertise is developed through transforming and integrating theoretical, practical and self-regulative knowledge. According to the review, this can be achieved by offering professionals multiple opportunities for problem solving, reflection, learning from errors and boundary crossing.

While it is beyond the scope of this paper to examine the different forms of WBHE programmes or academic-industry partnerships in detail, it is useful to note that the diversity of the programmes results in multiple different learning environments and thus, have an influence on how the professionals develop and learn. Since work-based learning (WBL) is a situated process that "takes place in and between different contexts" (Lucas 2007, 98), it is important to pay attention to how these academic-industry partnerships are executed and how they support or restrict the development of expertise. Basing learning around work does not automatically lead to better results and it has been suggested that academic-industry partnerships may actually hinder the development of work-based programmes if both parties are not fully committed (Reeve and Gallacher 2005). In order to unleash the full potential of WBHE, there is a need to take into account not only the individuals' motivations, aspirations and potential for development, but also organisational cultures and dynamics (Lester \& Costley 2010). As Lester and Costley $(2010,563)$ have stated, "work-based learning will only 'work' if the work environment is capable of supporting learner-managed, reflective learning at an appropriate level."

From our findings, we have formulated four general guidelines or principles that should be considered when designing postgraduate WBHE, to support the professional development of experienced professionals. In view of the diversity of work-based 
programmes and learners, these guidelines do not recommend any specific practical tools or best practices, but rather illustrate what kind of learning processes should be supported and what needs to be acknowledged when designing WBHE programmes for professionals. 1. Allow the learners to self-manage their learning through reflection in order to build agency and self-regulative skills. Provide autonomy but at the same time provide support if necessary.

The findings indicate that self-directed learning and autonomy are important when developing the expertise of competent practitioners. This is in line with Grenier's (2009, 154-155) views that 'learners need to take charge of their own development through continuing education, self-directed learning, and reflection on prior experiences in order to move from competence to expertise'. In addition to autonomy, the reviewed studies highlighted the value of social support during the studies. Fellow students, mentors and other facilitators help learners reflect on and view their work from different perspectives, helping them become aware of unconscious behaviours and re-evaluate their understandings (see Dalrymple, Kemp, and Smith 2014).

2. Provide opportunities for learners to continuously solve ill-defined, non-routine problems and create challenges that trigger learning.

Problem solving has been identified as key component of expertise development. In particular, solving ill-defined, non-routine and troublesome problems as well as learning from mistakes are important factors that push the professionals to develop their capabilities and expertise. The problems can be related to the professionals' practical work and daily challenges, or even to their personality and development as a professional, i.e. professional identity. The value of mistakes and errors as a source for learning, rather than embarrassment, should be acknowledged by both the learners and the facilitators (see Cannon and Edmondson 2005). However, informal learning contexts alone do not promote development 
of meta-competences and higher order thinking skills (Chivers 2007). Application of conceptual resources (and related tools) in authentic work settings, for example, by combining university level theoretical studies with theory-based practical training, develop professionals ability to apply theoretical understanding in practical contexts (Finlay 2008; Slotte and Tynjälä 2003; Vollmer et al. 2013).

\section{Support the learners' personal transformation process and change of identity.}

A key issue in the expertise development of professionals is the transition between different environments and boundaries. Moving between different disciplines and environments may result in a blurring of contexts, identities and roles. Even though professionals are usually experts in their own fields, they might be unfamiliar with the university setting and unaware of how they learn and operate as professionals (see Dalrymple, Kemp, and Smith 2014). Reviewed studies emphasized the importance of supporting professionals' development of self-regulative and metacognitive knowledge (e.g., Chivers 2007; Costley 2010; Slotte and Tynjälä 2003; Tynjälä, Välimaa, and Sarja 2003) by providing time, support and opportunities to critically reflect on their professional contribution, to reconstruct the meaning of their experiences and to more widely reflect on their professional identity (see Stephenson, Malloch, and Cairns 2006).

\section{Acknowledge that expertise development is an ongoing, context-dependent and} individualised process by providing multiple opportunities for participation and learning according to individual needs.

The review supports the notion that expertise development is not as linear as some traditional stage models present (e.g., Dreyfus and Dreyfus 1986), but rather a continuous and context-dependent process. Professionals today must continuously adapt their expertise to new situations, scenarios and contexts (Grenier and Kehrhahn 2008). Further, because professionals develop their expertise in a wide variety of ways, it is important to guard 
against 'being too prescriptive in respect of "best practice" learning methods' (Cheetham and Chivers 2001, 285).

Some limitations of this review are to be considered when interpreting the findings. The diversity of different WBHE programmes is captured in the review by several forms of education. This diversity and lack of consistent naming of the programmes may have biased the findings, as some forms of education may be over- or under-represented. Moreover, the review covers more qualitative than quantitative studies, and the studies were also mostly conducted in Europe.

In this review our aim was to provide a deeper understanding into how previous research has described the development of expertise in work-based postgraduate higher education by integrating and synthesizing existing research. Thus, we included both empirical and conceptual research articles in the literature review in order to summarize prior knowledge and to formulate a more comprehensive picture of this emerging topic. In this review approximately one third of the included studies are conceptual and it is apparent that in the future there is a need to expand especially the amount of empirical research done in the field.

Our literature search revealed that even though expertise development has been studied for decades and a large amount of research exists in the field, only a few studies consider how higher level expertise is developed during WBHE. This is in line with Chivers' (2007) arguments that research on professional learning and development during higher education has been strongly focused on young, full-time students who study at undergraduate level. However, as the knowledge economy calls for practitioners to engage in continuous professional development and given the increasing prevalence of WBHE programmes, there is a growing need for further research to expand our understanding on how experts and experienced practitioners learn and develop professionally during WBHE. 


\section{References}

Akkerman, S. F., and A. Bakker. 2011. "Boundary Crossing and Boundary Objects." Review of Educational Research 81 (2): 132-169.

Armsby, P. 2013. "Developing Professional Learning and Identity through the Recognition of Experiential Learning at Doctoral Level." International Journal of Lifelong Education 32 (4): 412-429.

Baartman, L., J. Gulikers, and A. Dijkstra. 2013. "Factors Influencing Assessment Quality in Higher Vocational Education.” Assessment \& Evaluation in Higher Education 38 (8): 978-997.

Bereiter, C. \& Scardamalia, M. (1993). Surpassing ourselves. An inquiry into the nature and implications of expertise. La Salle, IL: Open Court.

Beighton, C., and S. Poma. 2015. "Expanding Professional Learning: Inside/Outside Police Firearms Training." Studies in Continuing Education 37 (2): 187-201.

Boud, D., and N. Solomon, eds. 2001. Work-based Learning: A New Higher Education. Buckingham: Society for Research into Higher Education \& Open University Press.

Boud, D., and C. Symes. 2000. "Learning for real: Work-based Education in Universities.” In Working Knowledge: The New Vocationalism and Higher Education, edited by J. McIntyre and C. Symes, 14-29. Buckingham: Society for Research into Higher Education \& Open University Press.

Brynjolfsson, E., and A. McAfee. 2014. The Second Machine Age: Work, Progress, and Prosperity in a Time of Brilliant Technologies. New York: WW Norton \& Company.

Cannon, M. D., and A. C. Edmondson. 2005. "Failing to Learn and Learning to Fail (Intelligently): How Great Organizations Put Failure to Work to Innovate and Improve." Long Range Planning 38 (3): 299-319.

Cheetham, G., and G. Chivers. 2001. "How Professionals Learn in Practice: An Investigation of Informal Learning amongst People Working in Professions.” Journal of European Industrial Training 25 (5): 247-292.

Chi, M. T. H. 2006. "Two Approaches to the Study of Experts' Characteristics.” In The Cambridge Handbook of Expertise and Expert Performance, edited by K. A. Ericsson, N. Charness, P. J. Feltovich, and R. R. Hoffman, 21-30. Cambridge: Cambridge University Press. 
Chi, M. T. H., R. Glaser, and E. Rees. 1981. Expertise in Problem Solving. Pittsburgh: Learning Research and Development Center, University of Pittsburgh.

Chivers, G. 2007. "Professional Competence Enhancement via Postgraduate Post-Experience Learning and Development." Journal of European Industrial Training 31 (8): 639659.

Collin, K., B. Van Der Heijden, and P. Lewis. 2012. "Continuing Professional

Development." International Journal of Training and Development 16 (3): 155-163.

Costley, C. 2010. "Doctoral learning that leads to organisational and individual change."

Work Based Learning e-Journal 1 (1): 177-201.

Costley, C. 2013. "Evaluation of the Current Status and Knowledge Contributions of

Professional Doctorates." Quality in Higher Education 19 (1): 7-27.

Costley, C., and S. Lester. 2012. "Work-Based Doctorates: Professional Extension at the Highest Levels." Studies in Higher Education 37 (3): 257-269.

Critical Appraisal Skills Programme (CASP). 2014. CASP Checklists. Oxford: CASP.

Retrieved from: http://www.casp-uk.net/checklists.

Dalrymple, R., C. Kemp, and P. Smith. 2014. "Characterising Work-Based Learning as a Triadic Learning Endeavour.” Journal of Further and Higher Education 38 (1): 7589.

Dreyfus, H., and S. Dreyfus. 1986. Mind over Machine: The Power of Human Intuition and Expertise in the Era of the Computer. Oxford: Basil Blackwell.

Ellis, S., and I. Davidi. 2005. "After-Event Reviews: Drawing Lessons from Successful and Failed Experience.” Journal of Applied Psychology 90 (5): 857-871.

Elvira, Q., S. Beausaert, M. Segers, J. Imants, and B. Dankbaar. 2016. "Development and Validation of a Supportive Learning Environment for Expertise Development Questionnaire (SLEED-Q).” Learning Environments Research 19 (1): 17-41.

Endedijk, M. D., and L. H. Bronkhorst. 2014. “Students' Learning Activities within and between the Context of Education and Work." Vocations and Learning 7 (3): 289311.

Engeström, Y., R. Engeström, and M. Kärkkäinen. 1995. "Polycontextuality and Boundary Crossing in Expert Cognition: Learning and Problem Solving in Complex Work Activities." Learning and Instruction 5 (4): 319-336.

Engeström, Y. 2004. The New Generation of Expertise. Seven Theses. In Workplace Learning in Context, edited by H. Rainbird, A. Fuller, and A. Munro, 145-165. London: Routledge. 
Ericsson, K. A., R. Krampe, and C. Tesch-Römer. 1993. "The role of deliberate practice in the acquisition of expert performance." Psychological Review 100 (3): 363-406.

Ericsson, K. A. 2006. The Influence of Experience and Deliberate Practice on the Development of Superior Expert Performance. In The Cambridge Handbook of Expertise and Expert Performance edited by K. A. Ericsson, N. Charness, P. J. Feltovich, and R. R. Hoffman, 683-703. Cambridge: Cambridge University Press.

Eraut, M. 2004. "Informal Learning in the Workplace." Studies in Continuing Education 26 (2): 247-273. DOI: 10.1080/158037042000225245

Feldmann, L. 2016. "Considerations in the Design of WBL Settings to Enhance Students' Employability." Higher Education, Skills and Work-Based Learning 6 (2): 131-145.

Finlay, I. 2008. "Learning through Boundary-Crossing: Further Education Lecturers Learning in Both the University and Workplace.” European Journal of Teacher Education 31 (1): $73-87$.

Fleck, J. 1998. "Expertise: Knowledge, Power, and Tradeability.” In Exploring Expertise, edited by R. Williams, R. Faulkner, and J. Fleck, 143-172. London: MacMillian.

Garnett, J. 2016. "Work-Based Learning: A Critical Challenge to the Subject Discipline Structures and Practices of Higher Education.” Higher Education, Skills and WorkBased Learning 6 (3): 305-314. doi: https://doi.org/10.1108/HESWBL-04-2016-0023

Grenier, R. 2009. "The Role of Learning in the Development of Expertise in Museum Docents." Adult Education Quarterly 59 (2): 142-157.

Grenier, R., and M. Kehrhahn. 2008. Toward an Integrated Model of Expertise and its Implications for HRD.” Human Resource Development Review 7 (2): 198-217.

Guile, D., and T. Griffiths. 2001. "Learning through Work Experience.” Journal of Education and Work 14 (1): 113-131.

Hay, A., and D. Samra-Fredericks. 2016. "Desperately Seeking Fixedness: Practitioners' Accounts of 'Becoming Doctoral Researchers'.” Management Learning 47 (4): 407423. doi: $10.1177 / 1350507616641599$

Herling, R. W. 2000. “Operational Definitions of Expertise and Competence.” In Strategic Perspectives on Knowledge, Competence, and Expertise, Vol. 5, edited by R. W. Herling and J. Provo, 8-21. Baton Rouge, LA: Academy of Human Resources Development.

Van der Heijden, B. 2002. "Prerequisites to Guarantee Life-Long Employability." Personnel Review 31 (1): 44-61. 
Hibbert, P., and A. Cunliffe. 2015. "Responsible Management: Engaging Moral Reflexive Practice through Threshold Concepts." Journal of Business Ethics 127 (1): 177-188. Hytönen, K., T. Palonen, E. Lehtinen, and K. Hakkarainen. 2016. "Between Two Advisors: Interconnecting Academic and Workplace Settings in an Emerging Field." Vocations and Learning 9 (3): 333-359.

Jung, E., K. Minkyoung, and C. M. Reigeluth. 2016. "Learning in Action: How Competent Professionals Learn." Performance Improvement Quarterly 28 (4): 55-69.

Knight, L. 2002. "Network Learning: Exploring Learning by Interorganizational Networks." Human Relations 55 (4): 427-454.

Knowles, M. 1975. Self-Directed Learning. New York: Association Press.

Lave, J., and E. Wenger. 1991. Situated Learning: Legitimate Peripheral Participation. Cambridge: Cambridge University Press.

Leinhardt, G., Y. McCarthy, and J. Merriman. 1995. "Integrating Professional Knowledge: The Theory of Practice and the Practice of Theory." Learning and Instruction 5 (4): 401-408.

Le Maistre, C., and A. Pare. 2006. "A Typology of Knowledge Demonstrated by Beginning Professionals." In Higher Education and work: Collaborations, Confrontations and Challenges, edited by P. Tynjälä, J. Välimaa, and G. Boulton-Lewis, 103-113. Amsterdam: Elsevier.

Lester, S., and C. Costley. 2010. "Work- Based Learning at Higher Education Level: Value, Practice and Critique." Studies in Higher Education 35 (5): 561-575.

Lucas, N., and L. Unwin. 2009. "Developing Teacher Expertise at Work: In- Service Trainee Teachers in Colleges of Further Education in England." Journal of Further and Higher Education 33 (4): 423-433.

Lucas, N. 2007. "Rethinking Initial Teacher Education for Further Education Teachers: From a Standards- Led to a Knowledge- Based Approach." Teaching Education 18 (2): 93-106.

Merriam, S. 2001. “Andragogy and Self-Directed Learning: Pillars of Adult Learning Theory." New Directions for Adult and Continuing Education 89, 3-14.

Miles M. B., and A. M. Huberman. 1994. Qualitative Data Analysis. Thousand Oaks, CA: Sage Publications.

Mylopoulos, M., G. Regehr, and S. Ginsburg. 2011. “Exploring Residents' Perceptions of Expertise and Expert Development." Academic Medicine 86 (10): 46-49. 
Nokelainen, P., H. Kaisvuo, and L. Pylväs. 2017. "Self-Regulation and Competence in WorkBased Learning." In Competence-Based Vocational and Professional Education. Bridging the Worlds of Work and Education, edited by M. Mulder, 775-793. Cham: Springer International Publishing Switzerland.

Petty, N. J. 2015. "Becoming an Expert: A Masterclass in Developing Clinical Expertise." International Journal of Osteopathic Medicine 18 (3): 207-218.

Reeve, F., and J. Gallacher. 2005. Employer-university 'partnerships': A key problem for work-based learning programmes? Journal of Education and Work 18 (2): 219-33.

Rhodes, G., and Shiel, G. 2007. "Meeting the Needs of the Workplace and the Learner through Work-Based Learning." Journal of Workplace Learning 19 (3): 173-187.

Slotte, V., and Tynjälä, P. 2003. "Industry-University Collaboration for Continuing Professional Development." Journal of Education and Work 16 (4): 445-464.

Sense, A. 2016. "Work-Based Research Degrees: Systematic Cultivation through a University-Industry Network Space." Studies in Higher Education 41 (6): 933-954.

Stephenson, J., M. Malloch, and L. Cairns. 2006. "Managing Their Own Programme: A Case Study of the First Graduates of a New Kind of Doctorate in Professional Practice.” Studies in Continuing Education 28 (1): 17-32.

Torraco, R. J. 2005. "Writing Integrative Literature Reviews: Guidelines and Examples." Human Resource Development Review 4 (3): 356-367.

Tynjälä, P. 1999. “Towards Expert Knowledge? A Comparison between a Constructivist and a Traditional Learning Environment in the University." International Journal of Educational Research 31 (5): 357-442.

Tynjälä, P. 2008. "Perspectives into Learning at the Workplace.” Educational Research Review 3 (2): 130-154.

Tynjälä, P. 2013. "Toward a 3-P model of Workplace Learning: A Literature Review." Vocations and Learning 6 (1): 11-36.

Tynjälä, P., J. Välimaa, and A. Sarja. 2003. "Pedagogical Perspectives on the Relationships between Higher Education and Working Life." Higher Education 46 (2): 147-166.

Vollmer, S., H. Spada, F. Caspar, and S. Burri. 2013. "Expertise in Clinical Psychology. The Effects of University Training and Practical Experience on Expertise in Clinical Psychology." Frontiers in Psychology 4 (141): 1-12.

Wall, T. 2017. “A manifesto for higher education, skills and work-based learning: Through the lens of the Manifesto for Work." Higher Education, Skills and Work-Based Learning 7 (3): 304-314. 
Wenger, E. 1998. Communities of Practice. Learning, Meaning and Identity. Cambridge: Cambridge University Press.

Whittemore, R., and K. Knafl. 2005. "The Integrative Review: Updated Methodology.” Journal of Advanced Nursing 52 (5): 546-553.

Wright, A., and A. Gilmore. 2012. "Threshold Concepts and Conceptions: Student Learning in Introductory Management Courses." Journal of Management Education 36 (5): $614-635$.

Zimmerman, B. J. 2000. “Attaining Self-Regulation: A Social Cognitive Perspective.” In Handbook of Self-Regulation, edited by M. Boekaerts, P. R. Pintrich, and M. Zeidner, 13-39. San Diego: Academic Press. 